7ours and a half after death. - The whole surface of the body was of a deep livid colour, the arms and neck especially, the most dependant parts of which were almost black. The anterior parts of the abdomen and legs were less discoloured. The general expression of the face was that of a person who had been strangled or suffocated. The eyelids were puffy and odematous; also the scalp and face. The conjunctivæ were injected. The neck, chest, and upper arms partook of this general œdema. The abdomen was very tense and tympanitic on percussion. The rigor mortis had subsided in the upper extremities, but still existed in the lower. The spine was arched. The soles of the feet were flat and natural; the position of the latter was the same. The fingers and thumbs of both hands were firmly clenched, except the index fingers, which were extended and pointing downwards. The arms were extended along each side. The symmetry of the body was natural. The teeth were firmly set, the jaws rigid, the tongue protruded partly, the gums were bloodless, and the lips puffy and livid. Much bloody froth issued from both nostrils. Both cornex were opaque and dull; the pupils semidilated.

Internal Appearances, ffteen hours after death. - Much blood escaped on cutting through the scalp, and the oozing from the surface of the skull was unnaturally great. The vessels of the dura mater were much congested; the sinuses also. Some opacity of the arachnoid and pia mater was noticed, and the former was upraised by a rather thick, yellowish serum. The cerebral substance, both cortical and medullary, was much softened, and the puncta vasculosa very numerous. The ventricles contained rather more than the usual amount of serum. The spinal canal was filled with bloody serum; the proper vessels of the vertebræ were very prominent and congested, those on the anterior aspect of the arches quite as much as those on the posterior. The spine was opened immediately after the body was turned. The spinal membranes were of a bright scarlet, and seemed everywhere highly injected; the vessels coursing over the medulla oblongata were especially namerous, very tortuous, distended, and of a bright-red scarlet; this organ and the cord itself were less softened than the brain, but still abnormally so, and on close examination I thought the anterior columns were, if anything, more softened than the posterior. The cord partook of the general pathological character of the medulla, being soft and highly vascular. In the part corresponding to the dorsal region, its posterior aspect, a clot of blood, semi-fluid, covering a surface an inch and a half in extent, was found under the membranes. The convulsive movements noticed by the nurse as occurring chiefly on the right side, and in the convulsion which preceded death the right arm was thrown forcibly across the ehest, and remained there. Especial attention with reference to this phenomenon was paid on the examination of the nervous centres; bat, with the exception of greater turgidity, and injection of the left choroid plexus, nothing was found to account for it. The stomach contained about a pint and a half of semi-fluid, half digested food, composed of débris of meat, bread, potatoes, and fruit. Nothing beyond the ordinary appearances during digestion was noticed in its coats. The duodenum and jejunum appeared red and congested, but no traces of inflammatory action was perceived. The liver was large, congested, and in an advanced stage of cirrhosis; the gall-bladder contained about an ounce of bile. The kidneys were congested, the medullary structure in particular. The pericardium contained about an ounce of clear serum, of the natural colour. The heart was large, flabby, and collapsed; its muscular coat was greasy. The large bloodvessels and auricles were remarkably devoid of blood; the little they did contain was quite fluid, and stained their coats; it was very dark. Both ventricles contained each a clot of dark colour and semi-fluid; each clot weighed about a drachm and $a$ half. The lungs were voluminous, and filled the cavity of the chest; the posterior lobes were much congested; the bronchi and trachea were filled with bloody froth. The blood which escaped in cutting through their coats was quite fluid and very dark. This was the general character of the mass throughout the body. The muscles were of a rich red colour, exuded blood when cut into, and yielded it abundantly when squeezed. The bladder contained nearly a pint of bright, amber-coloured urine, of natural appearance.

Chemical analysis, thirty hours after death. The process re. commended by Messirs. Rodgers and Girdwood, in THE LANCET of June 2Sth, 1856, was gone through. Separate portions of the residue thus obtained were tried with bichromate of potash, with peroxide of lead, and with peroxide of manganese. All yielded the characteristic violet colour, less evanescent with the peroxide of lead than with the other two.
Nitric and sulphuric acids gave flashes of a blood-red colour, but not persistent.

The chloroform solution, evaporated to dryness on a thin glass plate, yielded a very minute crystalline mass, only visible as crystalline by a strong double lens. Under the microseope, it was composed of crystals, arranged in acicular tufts, radiating from a centre, there oblong plates with dihedral summits, and several globular amorphous masses. An alcoholic extract was also prepared from the decoction made with dilute hydrochloric acid, and this yielded, when evaporated on a watch-glass, a rather gummy, tenacious mass, which, under the microscope, presented star-like crystals, with their radii rounded. Both these masses, touched with a rod moistened by acetic acid, were dissolved in a few drops of water, and administered to a small toad. Several convulsions were produced, decidedly tetanic, resulting in death after about twenty minutes. The galvanic test described by Dr. Letheby in THe LANCET of June 28th, 1856, was also tried, and with a snccessful result. The reactions with perchloride of platinum, and with the iodide of potassium, on the acetic solutions, were also characteristic. The stomach was cut in pieces, and one half digested in alcohol, acidulated with hydrochloric acid, and boiled for two hours; then the liquid prepared and tested according to the process before mentioned. The other half was treated with water, acidulated by hydrochloric acid, and subjected to the same processes. The colour and galvanic tests yielded positive results with both.

In the experiments upon animals with the material composing the pills, rabbits and frogs were found to show the phenomena of strychnia-tetanus perfectly; but in point of delicacy and susceptibility to the action of the poison, I give decided preference to small toads. Five were killed by it, and they exhibited the phenomena, not only for a longer period, (twelve hours in two instances, ) but were almost immediately affected by doses which it took half an hour to produce convulsions in the frog. Their movements were more lively, the tetanoid spasms were brought on again by sounds, when they had ceased for awhile, and although no accurate notes of the doses, period of action, duration, and death were made, yet, in every respect, $I$ an inclined to look upon small toads as eminently strychnoscopic.

I may shortly publish a series of experiments, showing the minimum dose required to render these animals indicators of the presence of strychnia.

An analysis of two of the pills identified as being of the same kind as were taken by the deceased, yielded, by the chloroform separation process, nearly one quarter of a grain of almost pure strychnine, in the form of acetate, and possessing all the characteristics of this salt; hence we may assume that half a grail of commercial strychnia had caused death.

I cannot conclude the history of this case without stating that at the post-mortem examination, and more particularly during the analysis of the contents of the stomach, I received the greatest assistance from my friend, Mr. Vaudin, surgeon, of this place.

St. Helier's, September, 1856.

ON A CASE OH

CONGENITAL DROPSY, VESICULAR AND ANASARCOUS.

Bx W. THOMAS, Esq., F.R.C.S., Pembroke.

Tre following are the particulars of a case which occurred in my practice during the past summer, and considering them interesting to the profession, $I$ send them for insertion in the valuable columns of THE IANCET:-

Mrs. I-_- pregnant of her second child; the period of gestation unaccompanied by any abnormal symptoms until the latter part of the eighth month. She then had a severe attack of catarrh, with violent cough and copious expectoration, which continued some time, and required rather active treatment. The labix now began to swell, and to such an extent did it proceed, that to avoid pressure the thighs were obliged to be kept widely asunder, and she herself to lie flat on her back. The thighs, legs, and feet soon partook of the cedema. Scarifications relieved the enlargement of the pndendæ, but the other swellings did not subside completely until after parturition, which took place without any other untoward symptoms. The child when born was generally odematous, and had large vesicles over various parts of the body, especially the lower extremities. It was still-born, but had otherwise a healthy, mature appearance. 
Though in the course of an extensive midwifery practice of thirty years I have occasionally encountered these dropsical swellings of the external parts of generation, I do not recollect ever before having found the foetus congenitally thus affected.

Pembroke Dock, September, 1856.

\section{CASE OF}

\section{ABSENCE OF THE GALL-BLADDER IN A WOMAN AGED FIFTY.}

By EZRA HARLE, EsQ., L.S.A.

A. B—, who had had a family, died suddenly. The postmortem examination exhibited congestion of the brain. There was a large quantity of fluid in the chest. The liver, throughout its substance, was of a very dark-green colour, much resembling blue clay, but with a strong greenish hue.

After a careful examination by Mr. Pickess, of the Caledonian-road, and myself, we could not discover the gallbladder, nor any trace of the cystic duct.

Cross-street, Islington, Sept. 1856.

\section{A}

OF THE PRACTICE OF

\section{MEDICINE AND SURGERY IN THE}

\section{HOSPITALS OF LONDON.}

Nulla est alia pro certo noscendi via, nisi quam plurimas et morborum habere et inter se comparare-MorgagNI. De Sed. et Caus. Morb. lib. 14. Procemium.

\section{CASES OF RESECTION OF JOINTS.}

\begin{tabular}{|c|c|c|}
\hline \multirow{5}{*}{ KING'S COLLEGE } & \multicolumn{2}{|c|}{ Excision of Knee-joint ... Mr. FrRGUSSON. } \\
\hline & ", & Knee-joint ... \\
\hline & " & $\begin{array}{l}\text { Knee-joint } \cdots \\
\text { Knee-joint }\end{array}$ \\
\hline & 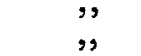 & Elbow-jaint ... Mr. FERGUSSON. \\
\hline & ," & Wrist-joint ... \\
\hline UNIVERSTTY & "פ & Knee-joint ... Mr. ERICHSEN. \\
\hline COLLEGE & ", & Knee-joint ... \\
\hline & 23 & Lioow-joint ... $\mathrm{Mr}$ " \\
\hline $\begin{array}{l}\text { GEORGF' } \\
\text { HOSPITAL }\end{array}$ & $\because$ & Knee-joint ... Mr. TATUM. \\
\hline &, & Mr. C. HAWKI \\
\hline & $"$ & Knee-joint ... Mr. HoLт. \\
\hline & 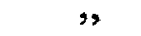 & Knee-joint ... \\
\hline $\begin{array}{l}\text { W ESTMINSTER } \\
\text { HosPITAL }\end{array}$ & $"$ & Elbow-joint... \\
\hline HOSFITAL & $"$, & Elbow-joint.... Mr. ḦоLTHoUse. \\
\hline & ", & Elbow-joint... \\
\hline BARTHOLOMEW'S & $"$ & Knee.joint ... Mr. STANLEY. \\
\hline HOSPITAL & 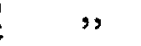 & Elbow-joint... Mr. LAw \\
\hline Gox's Hospital & ", & $\begin{array}{l}\text { Knee-joint ... Mr. BIRKETT. } \\
\text { Elbow-joint... }\end{array}$ \\
\hline & g & Elbovo-joint ... Mr. H'̈T \\
\hline & $"$ & Knee-joint ... Mr. Moone. \\
\hline $\begin{array}{l}\text { MIDDLESEX } \\
\text { HOSPITAL }\end{array}$ & $"$ & Hip-joint ... Mr. SHAw. \\
\hline Hospital & , & $\begin{array}{l}\text { Hip-joint } \ldots \\
\text { Elbow-joint }\end{array}$ \\
\hline & & Knee-joint ... Mr. SoUrH. \\
\hline $\begin{array}{l}\text { T. Thomas's } \\
\text { Hospital }\end{array}$ & 39 & Elbow-joint ... Mr. SoLLY. \\
\hline & & Elbow-joint... Mr. SIMoI \\
\hline $\begin{array}{l}\text { T. MARY'S } \\
\text { HOSPITAL }\end{array}$ & " & Elbow-joint ... Mr. WALTON. \\
\hline
\end{tabular}

WeSt HeRTs \{ Excision of Elbow-joint... Mr. Solly. INFIRMARY $\{$, Elbow-joint... ,

Metropolitan INFIRMARY,

(for Scrofula, ) at Margat
WE now present our readers with the records of the remain ing cases of excision of the knee-joint, which, with those given in the two preceding numbers, make the sixteen mentioned in our list above. Out of these there have been five deatlus: two from pyohæmia (Mr. Fergusson's and Mr. Tatum's); two from exhaustion and general debility (Mr. Cutler's and Mr. Holt's); and one from irritative fever (Mr. Moore's). Pyohæmia is one of those unfortunate occurrences which mar the success of so many of our most important operations, and is so completely beyond the control of the surgeon that we cannot be surprised that excision should form no exception to the general rule in the fatality of its results from such a cause. The exhanstion in Mr. Cutler's case was due to the long-continued suppuration and wearing out of the system, and to, most probably, what we suspected at the time, pulmonary phthisis ; but of this we have no direct proof, as an autopsy was not obtained. Much of the irritation in this case may have been due to the progress of ulceration of the articular cartilage of the tibia, which had been allowed to remain, and which, as we said before, to a certain extent excludes it from the category of true resections, and its failure therefore ought not to be included as testimony against the operation. Mr. Holt's case was the oldest patient upon whom the operation had as yet been performed. The patient-a woman, aged forty-seven years-who was in an exhausted condition before it was done, went on well up to the eighth day, but bed-sores over the sacrum destroyed life on the eighteenth day, from causes, we think, which might have infuenced the result, no matter what means might have been resorted to for relief. Mr. Moore's case most probably succumbed from the effects of the operation.

Amongst the recoveries are included two of subsequent amputation-Mr. Stanley's and Mr. Birkett's. Owing to some peculiar nervous state in an irritable constitution, the flexor tendons, in Mr. Stanley's case, were retracted to such an extent as to prevent the possibility of a favourable result; the limb could not be fixed even upon a splint, and at first required constant shifting; the wound therefore gaped, and a really very large raw surface was exposed, secreting quantities of matter. Division of the hamstring tendons might have proved beneficial here, and also in Mr. Price's two cases, where there was much rigidity existing at the time of the operation, and difficulty of stretching the limb. This was practised in Mr. Holt's female patient. The details of Mr. Birkett's case suff. ciently explain the necessity of amputation, independent of the mere excision of the joint.

The patella was retained in all but three instances; $\mathrm{Mr}$. Birkett found it necessary to remove it, as it was so much diseased-a rule that is invariably followed when this is the case. Of the propriety of retaining it, if not much affected, very few surgeons of experience will dispute; it forms a really important feature in strengthening the new joint; it is an excellent natural splint, if one may so call it; and it assists, moreover, in forming a solid anchylosis, and no doubt will be found to effect union between its lower margin and the divided end of the ligamentum patellæe. Of the many successful cases we have seen and minutely examined, the limbs are much firmer and stronger where this bone has been permitted to remain. The advantages of not cutting through the ligamentum patellæ, where practicable, as recommended by Mr. Jones, of Jersey, must be obvious.

There are several peculiarities of interest, which will suggest themselves to the mind of the reflecting surgeon, but which our limits will not permit us to dwell upon. We have thought it right to collect all these cases together, and we now leave them to the consideration of the profession, who will form their own conclusions as to the propriety of resection in any reasonable case, whether the joint may be diseased internally or exter. nally; whether it may be dislocated; or whether any condition is present, in fact, in which the patient is the possessor of an utterly useless limb. We do not believe the effort will be a great one to come to a determination on this point.

A word or two on the after-treatment. Let the operation be ever so skilfully performed, without great care and attention, patient watching, and an earnest desire at all times to attend to the various little cireumstances which present themselves-perhaps more so in this than any other operation, failure will be sure to result. We think more care is taken in the after-treatment of cases at some of our hospitals than at others, and this is even noticed by pupils attending the wards. No surgeon should undertake the operation unless he has quite made up his mind on this subject, and then may we expect, perhaps, a far greater amount of success than we have already 